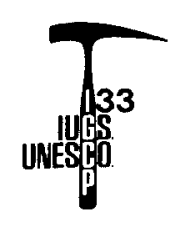

\title{
THE PHANEROZOIC TIME SCALE REVISITED
}

\author{
by
}

Gilles Serge Odin

\begin{abstract}
A synthesis of modern methodological and analytical results begun under IGCP Project 133 (Geochronology of Mesozoic and Cenozoic Deposits of Europe) has been completed with the help of more than 130 geologists and using dates obtained from 40 geochronological laboratories. The result is a recalibration of the Phanerozoic time scale presented here, with many important differences from previous schemes. The new ages will require the reconsideration of many relationships in the fields of sedimentology, palaeontology and tectonics.
\end{abstract}

\begin{abstract}
Un nombre considérable de données nouvelles est venu enrichir, durant les toutes dernières années, les possibilités de calibration de l'échelle des temps. Une synthèse de ces résultats tant méthodologiques qu'analytiques a été rédigée, avec la collaboration de plus de 130 géologues, d'après des mesures effectuées dans 40 laboratoires de géochronologie. La figure obtenue se distingue notablement du schéma ancien, trés succintement établi, et communément accepté. Les conséquences en seront perceptibles dans de nombreux domaines de la sédimentologie, de la paléontologie et de la tectonique.
\end{abstract}

\section{Introduction}

Efforts to establish a time scale for the Phanerozoic have a long story. In 1964, a symposium organized by the Geological Society of London summarized the state of the art and established a time scale which has remained unchanged (Harland et al, 1964), except for some local modifications due to stratigraphic reassessments or to recalculations using revised decay constants (e.g., Gale et al, 1979).

In more recent years there has been considerable work on this subject by many geochronologists. Some of this research was initiated by IGCP Project 133, which ran from 1975 to 1980 and tackled methodological as well as practical problems, especially for the Cretaceous and Palaeogene systems. A wide range of rocks and minerals were analyzed using potassium-argon, rubidium-strontium, uranium-lead and fissiontrack methods.

An up-to-date synthesis of the reliable data began three years ago in order to calibrate and revise the Phanerozoic time scale. Leading geochronologists, stratigraphers, palaeontologists and physicists around the world were invited to contribute their results. New and of ten unpublished data from some 130 geologists, including complementary and comparative dates from 40 geochronological laboratories, were published in a two-volume work (Odin, 1982). This work proposes a thoroughly revised time scale based on geochronological dates rather than on extrapolated ages using sediment thickness, constant biozone duration or regular sea floor spreading rates.

There is a clear need to revise the time scale because recently discovered stratigraphic, geochemical and analytical uncertainties have been largely underestimated in past calibrations of the stratigraphic column. The revised scale presented here will serve as a tool for determining the actual duration of phenomena such as biological, sedimentological or geochemical evolution and the sequence, duration and rate of evolution of tectonic and magmatic events.

\section{Stratigraphic Uncertainties}

Many of the older data were obtained on plutonic rocks whose stratigraphic relationships were not well known. In the newly proposed time scale most of these dates have been replaced by ones based on more accurately known geological units. The correct and extensive use of certain sedimentary geochronometers has also helped greatly to diminish the errors.

New understanding of the chemistry of geochronometers and modern analytical techniques for dating very small amounts of selected minerals have permitted, in some cases, the dating of rocks stratigraphically close to or at specific stratotypes. Stratigraphic uncertainties are therefore reduced to the problems of definition. Moreover, in recent years there have been many important revisions and reassessments of basic stratigraphic relationships and some of the problems of terminology and correlation which existed in 1964 have now been resolved.

\section{Geochemical Uncertainties}

There are many errors and unsolved problems concerning geochemical equilibrium of the isotopes used, from the time of crystallization until the time of the radiometric analysis itself. Although these problems have been known for a long time, most of them have only been solved in the past few years. The difficulty is that they are specific for each species of chronometer used and for each method of dating. A considerable amount of research has thus been necessary and has only been possible now that mass spectrometry has become a widely applied technique.

Glaucony: The process of genesis of green grains of marine origin and the geochemistry of the isotopes used to date them has been fully investigated in the past 10 years. Essential to the correct interpretation of this material is the distinction between the facies, characterized by green pellets and called "glaucony" (plural glauconies), and the authigenic minerals which make up the pellets (Odin and Matter, 1981). These diverse minerals range from a micaceous (glauconitic mica) to a smectitic (glauconitic smectite) end member.

The interpretation of radiometric results obtained will be completely different from one sample to another depending on the process of genesis and on the geochemical history of the green grains after burial. Detailed information is required on the nature of the initial substrate on which glauconitization takes place as well as on the time of burial and the subsequent history of the sediment.

For example, consider two slightly evolved glauconies of Eocene age. The first results from glauconitization of carbonate debris. Because no radiogenic isotopes are present 
in carbonates, this glaucony can, in the absence of later alteration, give an apparent age representative of the Eocene. After detailed study of the morphology and structure of the green grains, the second glaucony is recognized as the result of the glauconitization of coprolites coming from worms eating inherited clays. This glaucony will generally give an apparent age which is greater than the time of deposition and which is a compromise between the age of the inherited clay, frequently rich in radiogenic isotopes, and the time of glauconitization. The origin of the grains, their burial and tectonic history, and weathering effects must all be carefully studied, for these processes may have different consequences for the interpretation of $\mathrm{Rb}-\mathrm{Sr}$ or $\mathrm{K}$-Ar results.

A calculated apparent age may therefore be interpreted as a maximum or minimum age of deposition; in the ideal situation it will represent the age of the fossils located immediately above the dated level. This situation is quite different from that previously accepted by many geologists who regarded all glauconies as unreliable and giving too young apparent ages. In the past the usual method was to use the oldest apparent ages given by glauconies, but as shown in the example above this only leads to an overestimation of the age of deposition because of the inheritance of radiogenic isotopes in the substrate of glauconitization if not in the pellets themselves (see Odin, 1982, for other examples).

Figure 1A shows that Recent glauconies, less than a few tens of thousands of years old, show very old K-Ar apparent ages when the glauconitization of the initial substrate begins.

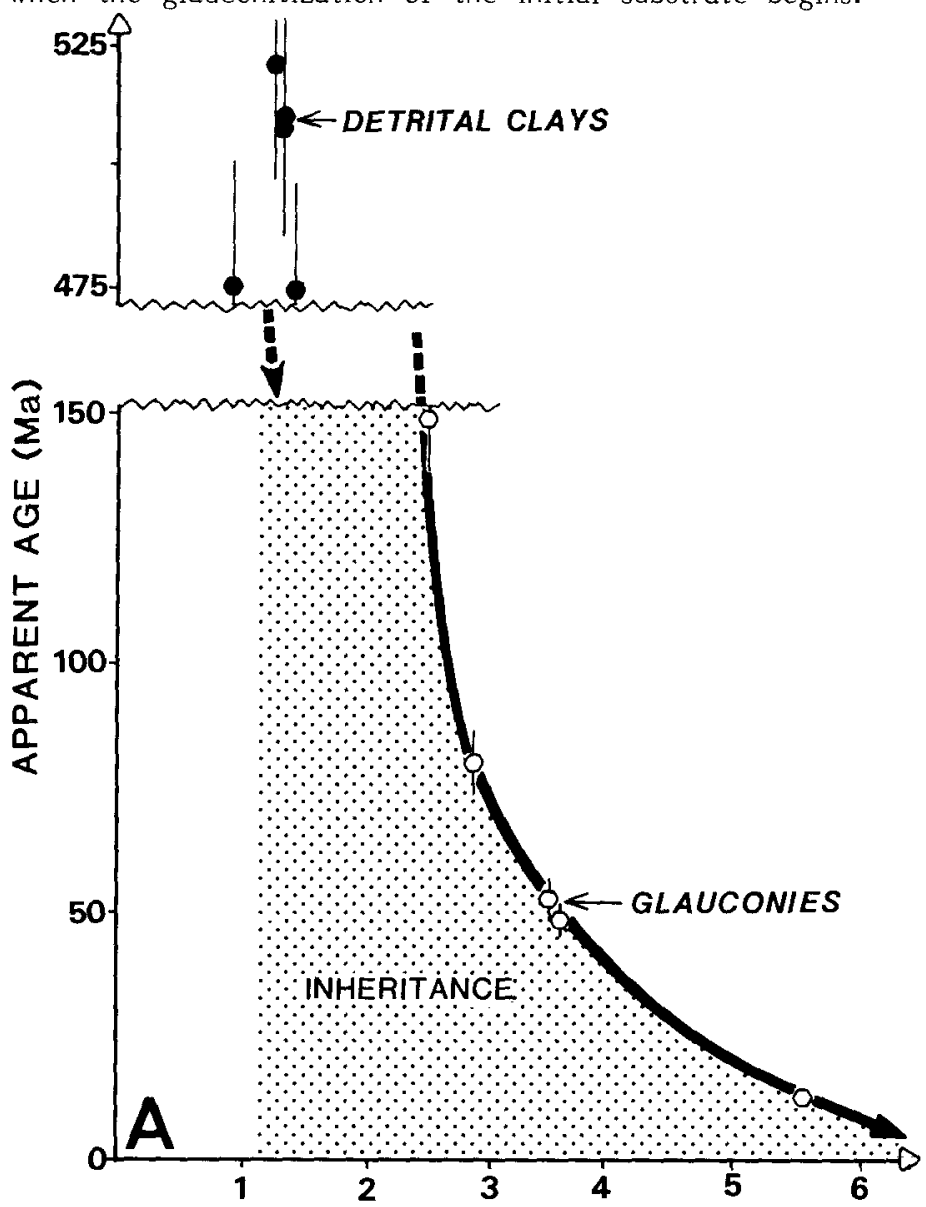

This apparent age diminishes as the process goes on, the $\mathrm{K}_{2} \mathrm{O}$ content increases and the Ar content decreases. Analyses of samples taken from the present sea bottom indicate that a glaucony forming from an $\mathrm{Ar}-$ or ${ }^{87} \mathrm{Sr}$-rich initial substrate, tends to a zero age only when its $\mathrm{K}_{2} \mathrm{O}$ content is above seven per cent. Consequently, all glauconies with a potassium content lower than this may give apparent ages older than the time of deposition and should therefore be considered suspect. Figure $1 B$ shows a similar example from the Miocene from NW Africa.

Apparent ages younger than the time of deposition were shown to be related to a burial of more than $1500 \mathrm{~m}$ or to a slight tectonic or volcanic event in the vicinity. The weathering process seems to rejuvenate Rb-Sr more than the $\mathrm{K}-\mathrm{Ar}$ apparent ages. This knowledge, now well exemplified and delimited, permits the selection of samples for analysis which are more likely to give an age near that of deposition. A test for the reliability of these apparent ages is now possible by dating different species of glauconitic minerals in a given formation. Finally, it should be pointed out that despite extensive research, the study of non-glauconitic clay minerals has not led to conclusive results useful for calibrating the Phanerozoic time scale.

Bentonite: Much recent work has been done on bentonites interlayered with marine formations dated palaeontologically, as in the U.S. Western Interior (Kauffman, 1969; Obradovich and Cobban, 1976). One of the interesting features of these layers (as well as tuffs, cinerites, etc.) is

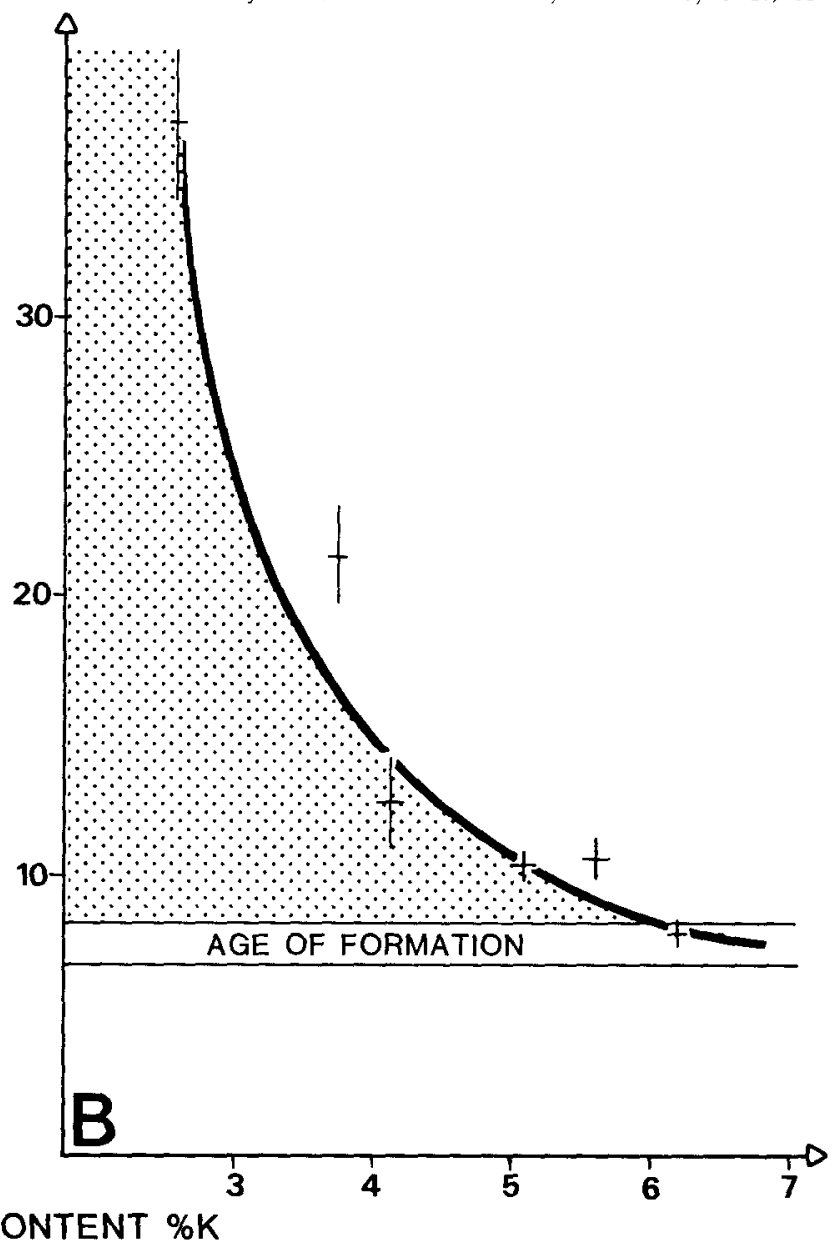

Figure 1: Glauconies giving apparent ages older than the age of deposition. A: Little-evolved glauconies from the Gulf of Guinea formed from coprolites deposited by worms eating clay and silt inherited from the weathering and erosion of the African Precambrian nearby. From sedimentological considerations the glauconitization is less than a few tens of thousand years old. B: Miocene glauconies from NW Africa of probable Tortonian age. Vertical axes show K-Ar apparent ages in Ma. 


\section{Table 1:}

Analytical results for North American bentonite minerals near the Cretaceous-Tertiary boundary (after Baadsgaard and Lerbekmo, in Odin 1982)

Method Mineral $\quad$ Apparent age Stratigraphy

\begin{tabular}{llll}
\hline $\mathrm{K}-\mathrm{Ar}$ & sanidine $: 7$ dates & mean $63.0 \mathrm{Ma}$ & samples above boundary \\
$\mathrm{K}-\mathrm{Ar}$ & sanidine $: 4$ dates & mean $63.3 \mathrm{Ma}$ & samples below boundary \\
$\mathrm{Rb}-\mathrm{Sr}$ isochron & biotites +1 sanidine & $63.6 \pm 0.4 \mathrm{Ma}$ & samples on the boundary \\
$\mathrm{U}-\mathrm{Pb}$ & zircon & mean $63.6 \pm 0.6 \mathrm{Ma}$ & samples on the boundary
\end{tabular}

$\mathrm{A}$ mean age $=63.5 \pm 0.4 \mathrm{Ma}$

that they may contain minerals of different geochemical behaviour. A multi-mineral, multi-method analysis may be undertaken to judge the reliability of the apparent ages obtained.

One example is given by studies of the Cretaceous-Tertiary boundary at the levels around the North American dinosaur disappearance (Baadsgaard and Lerbekmo, in Odin 1982). Table 1 summarizes the results obtained by these authors on much better material than that previously analyzed 10 years ago. According to the same authors, the main uncertainties arising when using bentonite minerals are the contamination by material coming from inherited crystal nuclei in the magma source, from older rock torn out of the volcanic vent, and from the solutions which transform the tuff through weathering to bentonite.

Another recent example is shown by Jeans et al. (1982) on bentonites from the Lower Cretaceous of southern England, where $\mathrm{K}$-feldspars give apparent ages clearly related to the basement. It is clear that the presence of older contaminants in bentonites and the fact that crystallization of minerals in the original tuff must predate the interlayering of the bentonite in a sedimentary sequence, will tend to result in an apparent age greater than that of the fossils deposited in the vicinity.

Volcanic Rocks: Special caution must also be exercised when using volcanics for calibrating the time scale. It is now well known that the use of whole-rock volcanics sometimes leads to unreliable ages due to recrystallization of the glassy component. The presence of excess argon leading to apparent ages older than that of the extrusion has been demonstrated in many deep submarine basalt samples since the work of Dalrymple and Moore (1968) and Funkhouser et al. (1968). However, recent $\mathrm{Rb}-\mathrm{Sr}$ isochron ages obtained for acid volcanics interlayered with or intruding Caledonian sediments show that when no rejuvenating process can be observed in the field, reliable ages may be obtained. This has been shown by comparison of apparent ages obtained on acid volcanics and granites of similar stratigraphic position (Gale, 1982, in Odin, 1982).

Plutonic Rocks: The most fundamental new idea for plutonics in the past two decades is that of the "blocking temperature", a concept largely developed from the studies of workers in Berne, Switzerland (Jäger and Hunziker, 1979). The blocking temperature is that at which the various isotopes become fixed in the crystal lattice; it varies depending on the mineral species, the isotope involved, and the rate of cooling, especially for the fission track method (Fig. 2). The apparent age calculated may represent different stages in the life of a pluton being dated. The age of the intrusion as well as that of many subsequent events, including the last heating above its blocking temperature defined by many studies, may thus be estimated. The use of plutonic rocks for calibration of the time scale therefore needs extensive petrological and radiometric studies to obtain an apparent age representative of the time of intrusion, when the pluton usually arrives in the stratigraphical sequence.

Summary: It may be concluded that modern research on the geochemical uncertainties shows that a calibration point for the time scale cannot be obtained without a comprehensive study in the field and the laboratory. For this reason the compilation of a reliable time scale, or part of it, needs careful discussion of the uncertainties associated with the stratigraphic control, quality of the radiometric analysis, and history of the geochronometer involved. Despite its obvious importance, the last factor is of ten neglected. The crucial point is that it is easy to distinguish the analytical result (the apparent age) from the geological significance of this number, which is generally less certain.

At this point one is reminded of a quote from Emilie Jäger: "Would you please determine one or two ages for me?" This sentence is well known to every geochronologist. Usually, it is much better to refuse. In most cases it needs 10 times more data to explain the first two results (Jäger and Hunziker, 1979, p. 5).

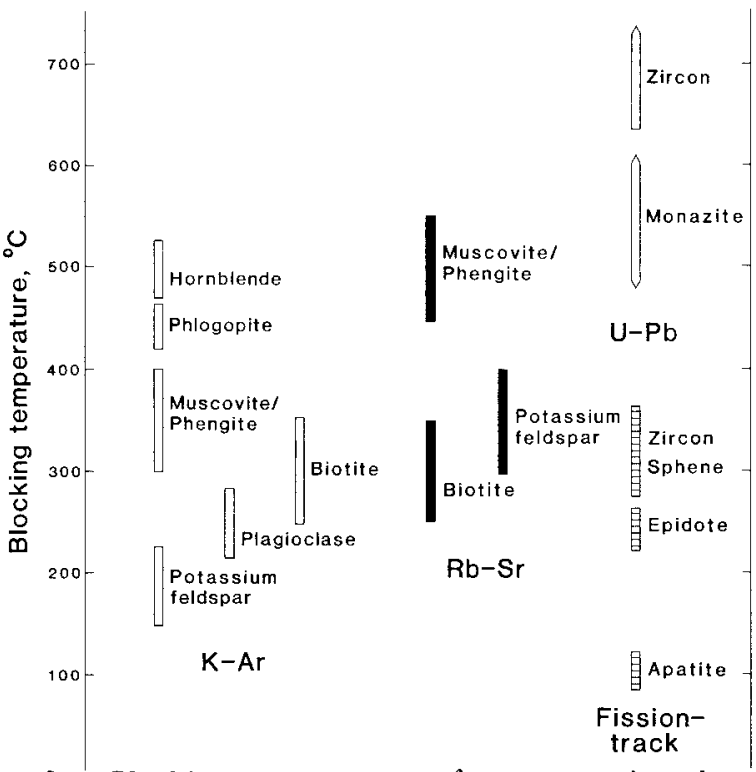

Figure 2: Blocking temperatures for some minerals and methods. $\quad U-\mathrm{Pb}, K-A r$ and $R b-S r$ data from Jäger and Hunziker, 1979. Fission-track data are from $M$. Selo and $D$. Storzer (personal communication, 1982), though other estimates may be proposed, especially for zircons which may lose tracks at temperatures as low as $180^{\circ} \mathrm{C}$ if these are maintained for a few million years. 


\section{Analytical Uncertainties}

In the past 10 years analytical uncertainties have diminished, and new techniques such as the 39/40 Ar method and the step-by-step heating approach have been developed. A new method, fission-track dating, is also now utilized. It must be emphasized, however, that the analytical uncertainties are much larger for this dating method than for any other, in part because of unsolved problems in calibration. Storzer and Wagner (in Odin, 1982), show that a realistic estimate of these uncertainties reach 6-10 per cent (20) of the apparent age, i.e., twice that for a routine $\mathrm{K}$-Ar analysis in the most favourable case. As a result, in its present stage of development, and despite the arguments of Ross et al. (1982) which do not fully discuss the possibility of systematic error, the fission-track method is not now suitable for precise time scale calibrations, except for very young ages.

Finally, since 1976, a single set of physical and chemical decay constants, probably correct at better than one per cent, have been accepted by geochronologists (Steiger and Jäger, 1977), though fission track constants are not included in this set. Former ages must therefore be recalculated with these values.

For all the reasons quoted above, the 1964 time scale of the Geological Society of London must be considered obsolete today. The use of modern standards of calculation and selection of chronometers and new interpretations of the analytical results have shown that many of these older estimates must be revised. Instead of the former estimates of the precise boundaries based more or less on empirical statements, the present study proposes intervals of time in which many of the stratigraphical boundaries are probably located.

\section{The Modern Phanerozoic Time Scale}

Neogene and Quatemary: An acceptable stratigraphy for these intervals has not been found and thus there are no limits to date. Moreover modern developments in palaeomagnetism have permitted calibrations based on magnetostratigraphy, rather than on radiometric dating. Consequently the focus of this study has been on older stratigraphic units.

Palaeogene: The time scale for the Palaeogene is now well documented in the NW European Tertiary basins where stratotypes have been clearly defined (see also Conference Report on NW European Tertiary in this issue of EPISODES). Figure 3 shows this scale using the best available data, with some elements different from those previously accepted. Multiple methods of analysis involving, most importantly, a variety of laboratories have been undertaken in this study to

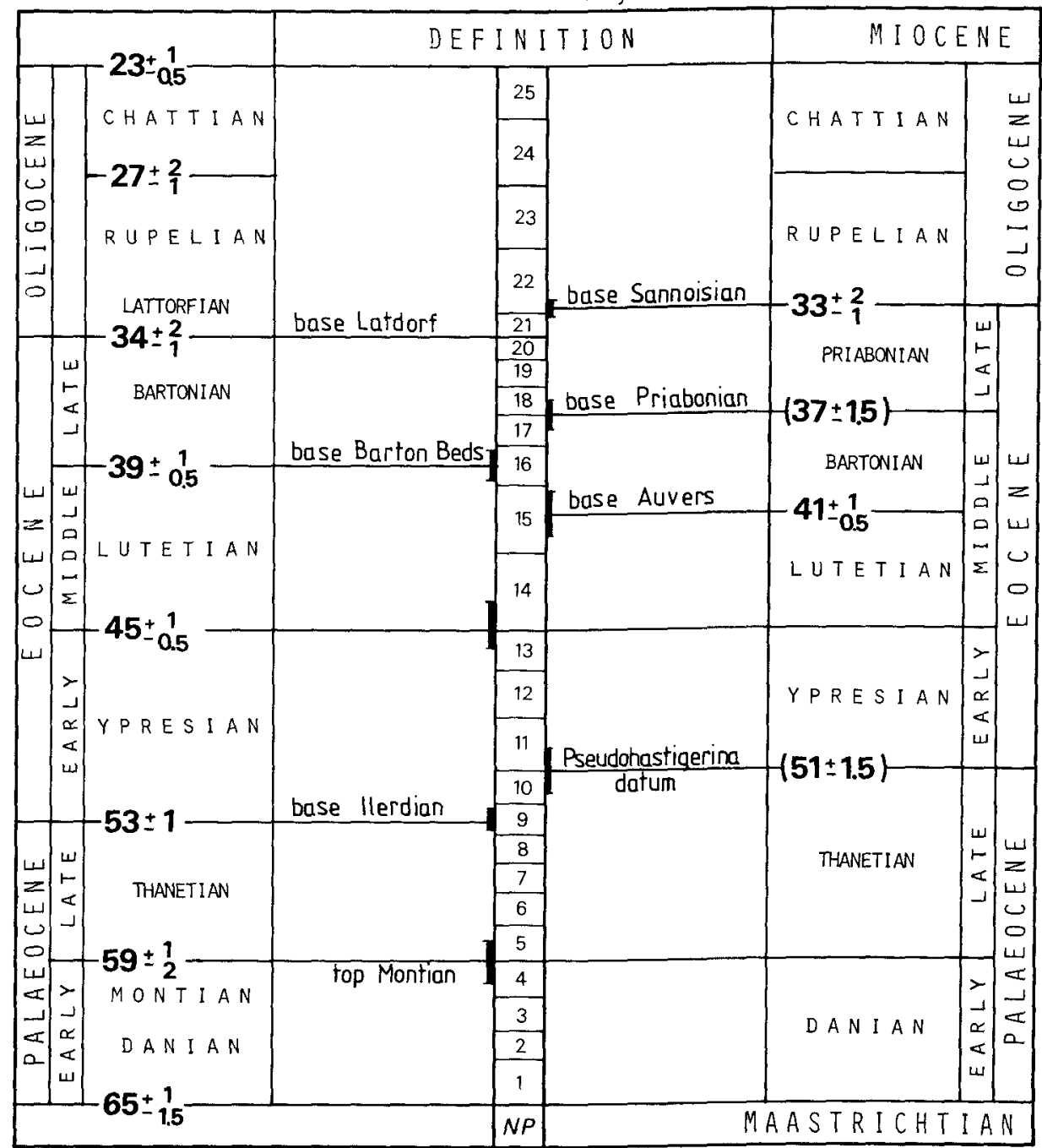

Figure 3: The Palaeogene time scale. Shown at the left are the classic lithostratigraphic units and on the right recently proposed definitions. The central column shows the nannoplankton biozone numbers, and the black bars indicate biostratigraphic uncertainties in correlating lithostratigraphic units with nannofossil biozones. Numbers in parentheses are extrapolated on the basis of relative sedimentary thicknesses and biostratigraphic divisions. 
diminish possible systematic deviations. Numerous samples from a single horizon and collected from different outcrops were selected in order to demonstrate sufficient reproducibility and to demonstrate that the chronometers used were truly representative. Dates on volcanic rocks from Europe as well as on selected glauconies from North America, all well located in the stratigraphic column, clearly confirm and were integrated in the scheme illustrated in Figure 3 (from Curry and Odin, in Odin, 1982, p. 607-632).

Mesozoic: Figure 4 shows the revised time scale for the Mesozoic, based on a variety of coherent dates obtained in Europe as well as in other parts of the world from volcanics, and bentonites (Odin and Kennedy, 1982). Glauconies were also used for the Jurassic and the Cretaceous.

Considerable progress in the knowledge of the Triassic has come from the work of Webb (in Odin, 1982, p. 515-522) and Armstrong (ibid., p. 509-514). Instead of five inaccurate dates available in 1964, nearly 30 calibration points are proposed in our synthesis (Odin and Létolle, in Odin, 1982, p. 523-536), each documented by numerous analyses.

The progress for the Jurassic and Cretaceous has been less spectacular, but the dates now being used are much better documented. This part of the time scale clearly shows that all stages are not of equivalent duration (an hypothesis previously accepted without sufficient data). An application of this scheme to known biozones shows that their durations are also unequal. Nevertheless, in the absence of other information, Kennedy and Odin (in Odin, 1982, p. 557-592) have proposed estimates for the early Jurassic using rather unreliable extrapolations based on the number of ammonite biozones.
Palaeozoic: The calibration of the Palaeozoic depends primarily on high temperature minerals and rocks, many from igneous plutons. Stratotypes were scarcely used and large stratigraphical uncertainties had to be taken into account when compiling Figure 5 after the syntheses of Gale (in Odin, 1982, p. 467-486) and Odin and Gale (ibid., p. 487-500).

Again, the dates obtained differ from many of the previous estimates. Note especially the absence of subdivision of some systems as well as the extrapolated boundaries (dotted lines) shown between many stages or series. Thus there are still many approximations and a number of undated boundaries for which information is lacking. Despite the uncertainties, however, new mean ages are suggested for a number of important boundaries.

One of the most important findings is the dating of the Cambrian system boundaries. The top is not well documented but is probably near $495 \mathrm{Ma}$ old. The base was indirectly dated by basement rocks clearly prior to an early Cambrian marine transgression in five sites located in England, France, Morocco, and the Sinai. The remarkable coherence of these results, together with a reassessment of the previously used calibration points, leads to the conclusion that the base of the system cannot be older than $540 \mathrm{Ma}$ (Odin et al, 1982). This age, much younger than proposed earlier, is founded on better analytical results and geochemical considerations than available earlier (see also "Chronology of the Geological Record", EPISODES, v. 1982, No. 2, p. 26).

The consequences of this new result for the base of the Phanerozoic has important implications for the story of biological evolution, since the Cambrian saw most of the
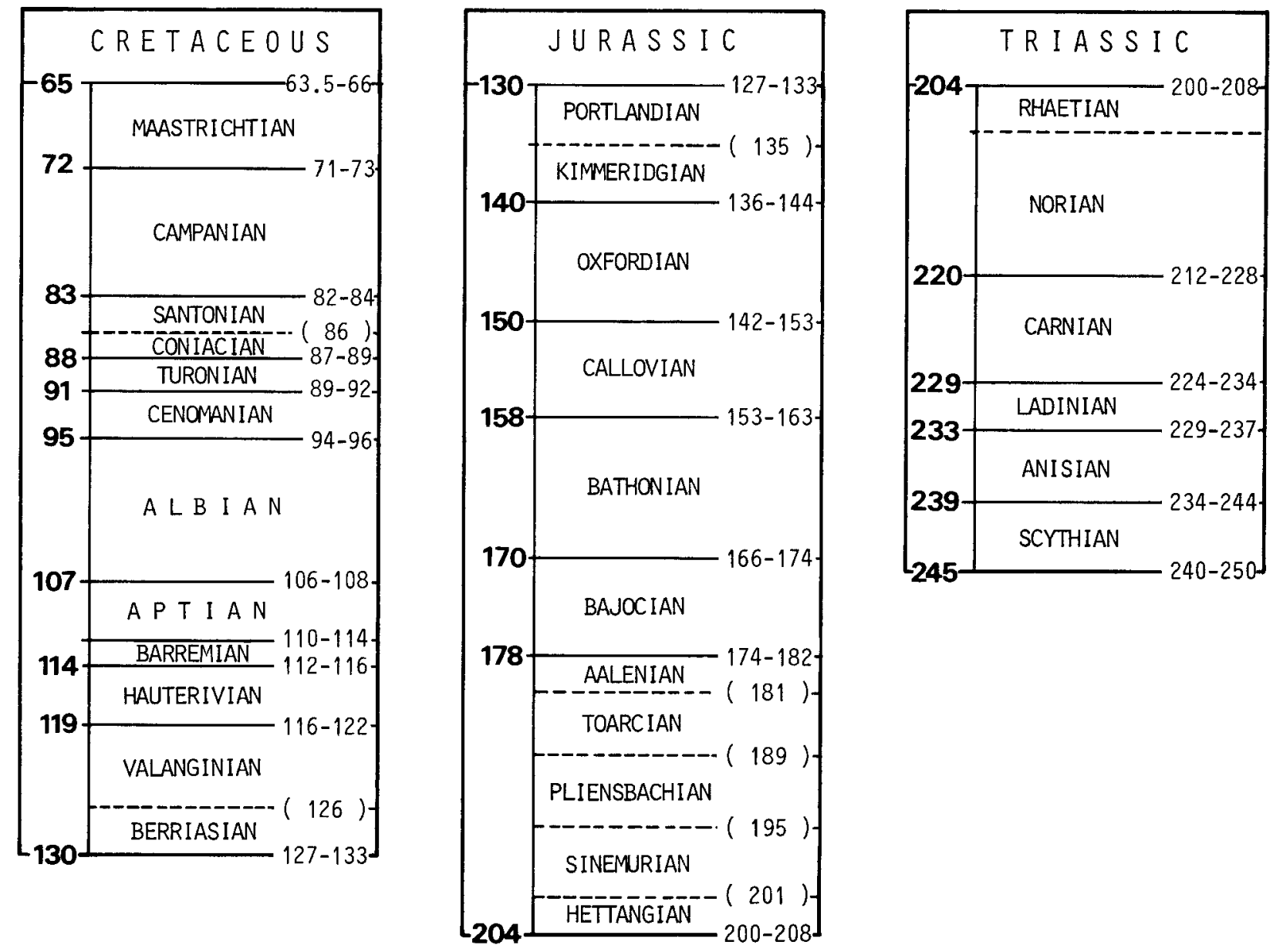

Figure 4: The Mesozoic time scale: Numbers on the right hand side of each column indicate the upper and lower limits within which the boundaries lie. Those in bold type on the left are the recommended means. Dashed lines and numbers in parentheses are extrapolations. 

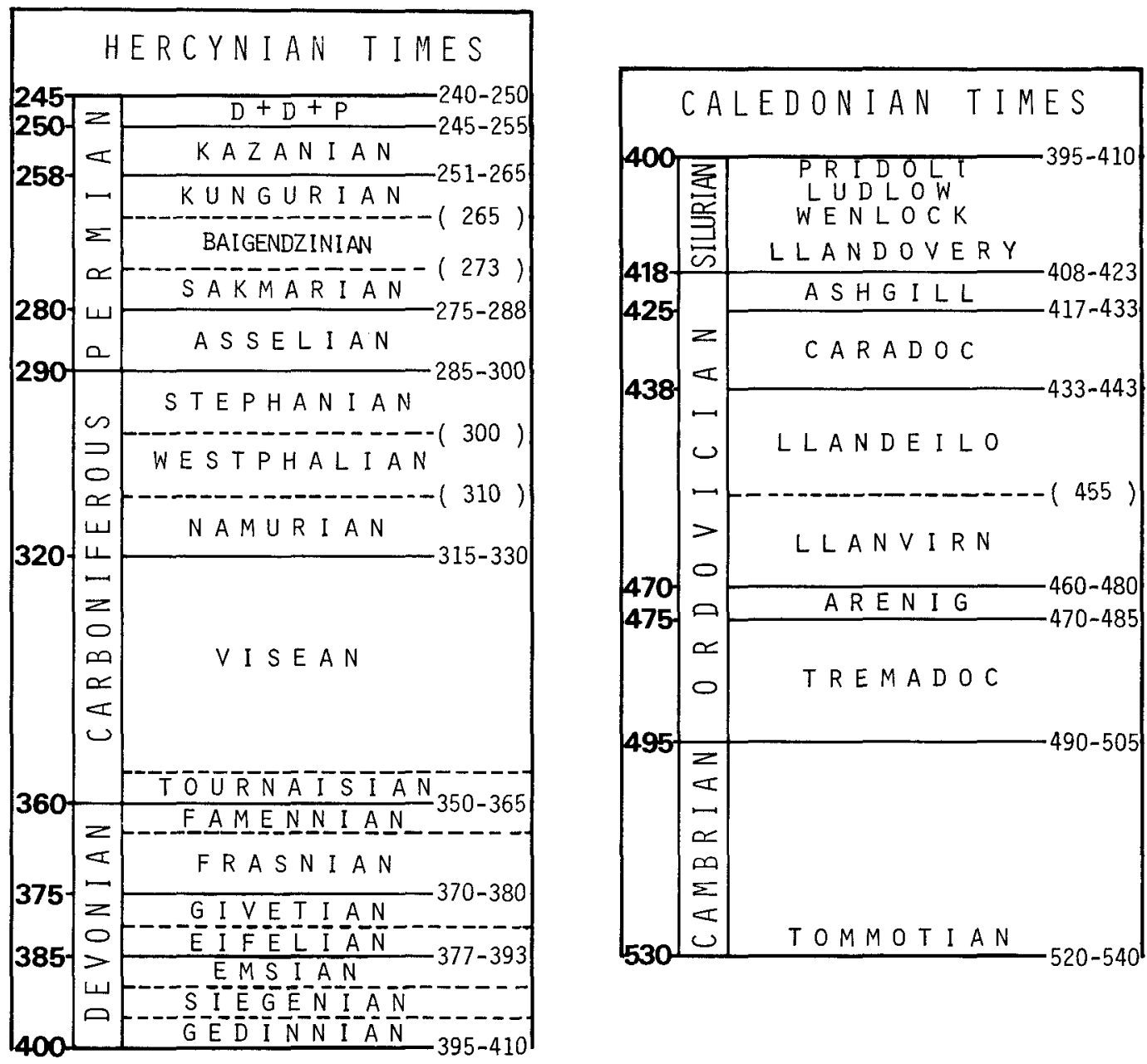

Figure 5: The Palaeozoic time scale: Legend as for Figure 4. Note the many uncertainties. Several new stage names recently proposed by stratigraphers have been included. The last stages of the Permian are the Punjabian, Djulfian, Dorashamian from oldest to youngest.

differentiation of the invertebrate phyla. If its timespan was indeed around $35 \mathrm{Ma}$, there may have been a faster rate of evolutionary change compared with later times.

\section{Conclusions}

The time scale proposed here is based on considerable progress in the knowledge of the geochemistry of materials used by geochronologists. The present author has tried to gather all the recent and independent results scattered throughout the literature with the collaboration of the authors of these measurements. New research has been undertaken, and the results have led to a time scale more secure than previously. This geological tool must be used with considerable care, keeping in mind that a given boundary is only defined within an interval of time, both the age limits of the interval and the calculated mean being equally possible.

Much crucial information is still lacking, especially for the Palaeozoic, and a proposal is therefore being made for a new IGCP project to refine the Phanerozoic time scale. This proposal has already received support from a number of countries and should help to resolve some of the remaining problems quoted above. Indeed research is already under way and it is hoped that results as effective as those obtained in the past few years will emerge.

\section{Acknowledgements}

The work reported in this paper began as part of IGCP Project 133. I am greatly indebted to the many colleagues who patiently answered my requests over the past three long years for more information on their own samples, their analytical procedures and results, and for more stratigraphical details. I hope they will be satisfied by this synthesis and will be encouraged to continue their work in this important aspect of geochronology. Nothing could have been done without their formal or informal written communications. To each of them my sincere thanks.

\section{References Cited}

Dalrymple, G.B. and Moore, J.G., 1968, Argon 40: excess in submarine pillow basalts from Kilauea Volcano, Hawaii: Science, 161 , p. 1132-1135.

Funkhouser, J.G., Fisher, D.E. and Bonatti, E., 1968, Excess argon in deep sea rocks: Earth Planetary Science Letters, 5, p. $95-100$.

Gale, N.H., Beckinsale, R.D. and Wadge, A.J., 1979, A Rb-Sr whole rock isochron for the Stockdale Rhyolite of the English Lake District and a revised mid-Palaeozoic timescale: J1. Geol. Soc. Lond., 136, p. 235-242. 
Harland, W.B., Smith, A.G. and Wilcock, B. (Eds.), 1964, The Phanerozoic Time-scale: Geological Society of London Special Paper 1 (Supplement to Vol. 120 of Quarterly Journal of Geological Society of London), 458p.

Jäger, E. and Hunziker, J.C. (eds.) 1979, Lectures in Isotope Geology: Springer-Verlag, Berlin, 312p.

Jeans, C.V., Merriman, R.J., Mitchell, J.G. and Bland, D.J., 1982, Volcanic clays in the Cretaceous of Southern England and Northern Ireland: Clay Minerals, 17, p. 105-156.

Kauffman, E.G., Population systematics radiometrics and zonation: A new biostratigraphy: in Correlation by Fossils: North Amer. Paleont. Convention Proc., 1970. Part F, p. 612-666.

Obradovich, J.D. and Cobban, W.A., 1975, A time scale for the late Cretaceous of the Western Interior of North America: Geol. Assoc. Canada, Spec. Paper 13, p. 31-54.

Odin, G.S. (ed.), 1982, Numerical Dating in Stratigraphy: John Wiley and Sons, Chichester, 2 vol., 1040p.

Odin, G.S., Auvray, B., Bielski, M., Gale, N.H., Lancelot, J.R. and Pasteels, P., 1982, La base du phanérozoïque est âgée de 520 à 540 Ma: C.R. Acad. Sci. Paris, 294, p. 1009 1012.

Odin, G.S. and Kennedy, W.J., 1982, Mise à jour de l'échelle des temps mésozoïques: C.R. Acad. Sci. Paris, 294, p. 383-386.

Odin, G.S. and Matter, A., 1981. De glauconiarum origine: Sedimentology, 28, p. 611-641.
Ross, R.J. Jr., Naeser, C.W., Izett, G.A., Obradovich, J.D., Bassett, M.G., Hughes, C.P., Cocks, L.M.R., Dean, W.T., Ingham, J.K., Jenkins, C.F., Rickards, R.B., Sheldon, P.R., Toghill, P., Whittington, H.B. and Zalasiewicz, J., 1982, Fission-track dating of British Ordovician and Silurian stratotypes: Geol. Mag. 119, p. 135-153.

Steiger, R.H. and Jäger, E., 1977, Convention on the use of decay constants in geo- and cosmochronology: Earth Planet. Sci. Letters, 36, p. 359-362.

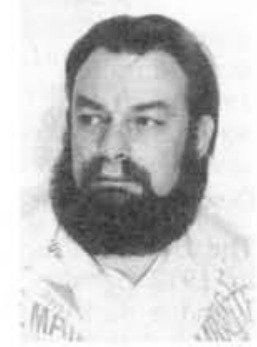

\section{ABOUT THE AUTHOR:}

Dr. G.S. Odin is Chargé de Recherche at the University Pierre et Marie Curie, Département de Géologie Dynamique, 4. place Jussieu, Tour 26, 4e étage, 75230 Paris Cedex 05, France. His research was first devoted to sedimentology and since 1975 to geochronology. His geochronological results were obtained as Fellow of the Universities of Berne, Leeds and Strasbourg and at the B.G.R. in Hannover, F.R.G. Dr. Odin was Leader of IGCP Project 133.

\section{NEW IUGS PUBLICATION}

\section{Publication No. 12:}

Ross, Reuben J. Jr. and F.J. Adler, T.W. Amsden, D. Bergstrom, S.M. Bergstrom, C. Carter, M. Churkin, E.A. Cressman, J.R. Derby, J.T. Dutro Jr., R.L. Ethington, S.C. Finney, D.W. Fisher, J.H. Fisher, A.G. Harris, L.F. Hintze, K.B. Ketner, D.L. Kolata. E. Landing, R.B. Neuman, W.C. Sweet, J. Pojeta Jr., A.W. Potter, E.K. Rader, J.E. Repetski, R.H. Shaver, T.L. Thompson, and G.F. Webers. THE ORDOVICIAN IN THE UNITED STATES. July, 1982, U.S.A. 73 p. with one correlation chart and explanatory notes. IUGS Publication No. 12: $\$ 10.00$ (U.S.). Sponsored by the International Subcommission on Ordovician Stratigraphy.

Available from:

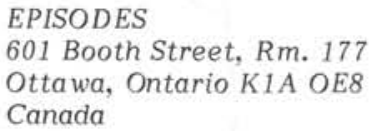

International Union of Geological Sciences Maison de la Geologie 77 , rue Claude Bernard 75005 , Paris, France

\section{NEW REPORT}

\section{IUGS Subcommission on Carboniferous Stratigraphy}

Ramsbottom, W.H.C., Saunders, W.B. and Owens, B. BIOSTRATIGRAPHY DATA FOR A MID-CARBONIFEROUS BOUNDARY. Leeds, U.K. 1982. Price: 5.00 pounds. Include articles on "Mid-Carboniferous biostratigraphy and boundary choices", A Mid-Carboniferous boundary based on conodonts and revised intercontinental correlations", Conodonts near the boundary between Lower and Middle Carboniferous of Donetz Basin", "The causes of faunal change in the Mid-Carboniferous" and "Brachiopods and the Lower-Middle Carboniferous (Mississippian-Pennsylvanian) boundary".

Available from:

\section{Chairman,}

Subcommission on Carboniferous Stratigraphy Institute of Geological Sciences

Ring Road Halton

Leeds LS15 8TQ, U.K. 